\title{
Why So Cynical? The Effect of Job Burnout as a Mediator on the Relationship Between Perceived Organizational Support and Organizational Cynicism
}

\author{
Fatimah A. Altamimi Shroque S. Alsubaie Abdelmohsen A. Nasaani \\ Department of Management, College of Business Administration, King Saud University, \\ P.O. Box 71115, Riyadh 11587, Saudi Arabia
}

\begin{abstract}
The current study represents a noteworthy step towards a better understanding of how perceived organizational support influences burnout and cynicism of healthcare staff. It explores whether perceived organizational support reduces job burnout and organizational cynicism and whether job burnout plays a mediating role in the relationship between POS and organizational cynicism. Data were collected from 211 personnel working in the healthcare industry in Saudi Arabia. Findings indicate that a high level of perceived organizational support ameliorates the experienced burnout symptoms, and allay cynical attitudes, emotions, and behaviors at work. The study also unfolds that burnout is mediating the relationship between POS and organizational cynicism, which highlights the importance of properly managing burnout. The study suggested that healthcare organizations should imperatively provide the necessary organizational support wherever and whenever it is needed and utilize the appropriate interventions to minimize the effects of burnout and cynicism. This is the first study that analyzed the impact of POS on organizational cynicism through the mediating variable of job burnout, and the first paper that investigates POS, organizational cynicism, and job burnout of healthcare staff in a single study. It adds to the growing body of literature on antecedents of organizational cynicism, job burnout, and POS as a mean to reduce negative workplace phenomena.
\end{abstract}

Keywords: perceived organizational support, job burnout, organizational cynicism, social exchange theory, job demand model, healthcare industry, healthcare staff.

DOI: $10.7176 / \mathrm{EJBM} / 13-7-04$

Publication date: April $30^{\text {th }} 2021$

\section{Introduction}

Organizational cynicism and job burnout are two occupational phenomena that have received scholarly attention over the past decades.(Dean, Brandes, \& Dharwadkar, 1998) introduced the concept of organizational cynicism as "a negative attitude composed of beliefs, affects, and behaviors", it has three main dimensions (Dean, et al., 1998; Ince \& Turan, 2011; Erarslan, et al., 2018). Several organizational factors found to be highly contributing to cynicism development: employees doubts regarding the organization's integrity, transparency, and fairness (Dean, Brandes, \& Dharwadkar, 1998), poor perceived organizational support, especially from the managers, (Cole, Bruch, \& Vogel, 2006), confusing and nonaligned organizational polices (Özer, Sonğur, Kar, Top, \& Erigüç, 2014), negative emotions in the workplace such as aggravation, anxiety, and frustration (Perrewé \& Zellars, 1999; Durrah, et al., 2019). Burnout has been recognized as an occupational syndrome that faces employees in people-oriented jobs such as healthcare, as these jobs are characterized by long hours, putting patients' needs first, and an intense level of personal and emotional contact (Maslach \& Leiter, 2016). Burnout syndrome is composed of three dimensions: emotional exhaustion, depersonalization, and inefficacy (Maslach, Jackson, \& Leiter, 1997). It is a consequence of problematic relationships between employees and their organizations, and when these problems last so long, the syndrome of burnout becomes chronic and significantly impacts the employees' well-being and organizational performance (Leiter \& Maslach, 2018).

The atmosphere of healthcare jobs usually results in high demand and low availability of desirable resources (Maslach \& Leiter, 2016), and requires sustainability of physical, emotional, and mental efforts; hence, it is associated with costs such as exhaustion and fatigue (Demerouti, Schaufeli, \& Nachreiner, 2001) and results in depleting employees' capacity (Maslach \& Leiter, 2008). The job demand model of (Demerouti, et al., 2001) has stressed the importance of resource availability and social support in reducing burnout syndrome. Thus, organizational support as a form of social support (Ahmed, et al., 2011) should be imperatively provided to healthcare employees. Based on the theory of perceived organizational support (POS), "employees form a general belief regarding the extent to which their organizations care about their well-being and value their contributions" (Eisenberger, et al., 1986), POS is ensured when employees believe that help is available and will be given whenever is needed to perform their jobs effectively and to deal with stressful situations (George, Reed, Ballard, Colin, \& Fielding, 1993). POS has been found to be a vital predictor of organizational cynicism (Guzel et al., 2011; Kasalak \& Aksu, 2014; SOYSAL et al., 2017; Aly et al., 2016; Byrne, 2008; PEPLINSKI, 2014), and job burnout (Zeng, et al., 2020; Özyer, et al., 2016; Yaghoubi et al., 2014; Neves, et al., 2014; Grama \& 


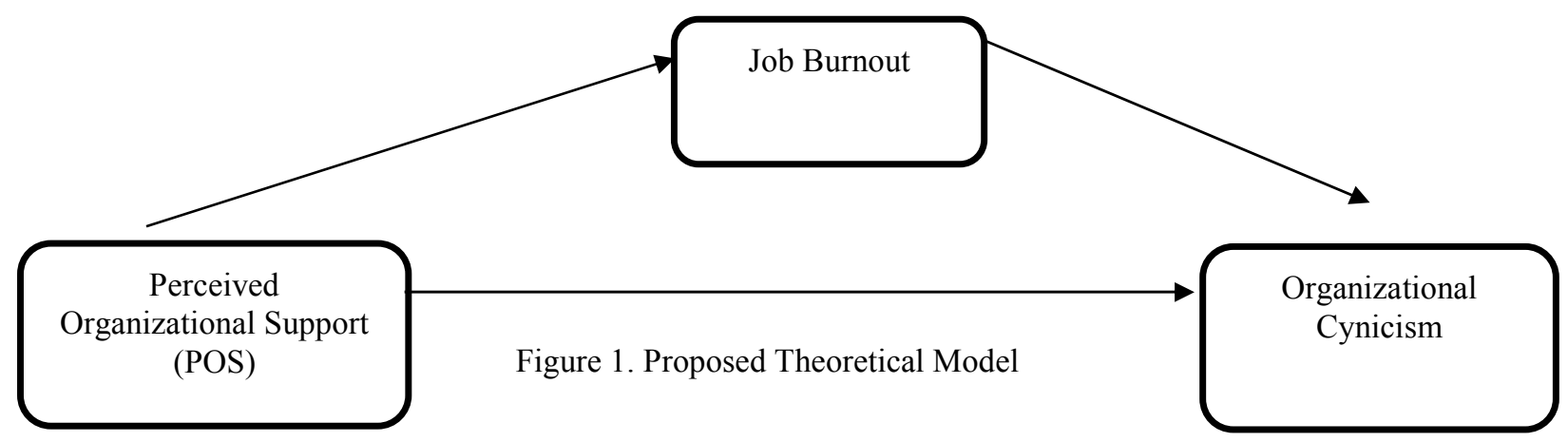

However, to the best of the author's knowledge, no study has analyzed the impact of POS on organizational cynicism through the mediating effect of job burnout of healthcare staff in Saudi Arabia. The current study adds to the existing body of literature by testing the model presented in Figure 1, suggesting (a) a direct relationship between perceived organizational support and organizational cynicism, (b) a direct relationship between perceived organizational support and job burnout, (c) a direct relationship between job burnout and cynicism and (d) proposing that job burnout mediates the relationship between perceived organizational support and organizational cynicism.

\section{Literature Review \& Hypothesis Development}

\subsection{Perceived Organizational Support and Job Burnout}

Burnout is associated with many undesirable organizational outcomes such as withdrawal, turnover intention, decreased productivity, reduced loyalty (Maslach, Schaufeli, \& Leiter, 2001), absenteeism, and low morality (Al-Omari, Al Mutair, Shamsan, \& Al Mutairi, 2019). These undesirable consequences are directly linked to financial losses and organizational ineffectiveness (Walters \& Raybould, 2007). The burnout phenomenon is observed in almost every service-providing profession (Ksiazek, Stefaniak, Stadnyk, \& ziazek, 2011). Burnout has been identified as a three-dimensional symptom of emotional exhaustion, depersonalization, and inefficacy (Maslach, Jackson, \& Leiter, 1997). Emotional exhaustion is being consumed by emotional stressors in the workplace, depersonalization is a feeling as of being disconnected from the surrounding environment, (Nurka, et al., 2014), and the inefficacy dimension basically means a decreased sense of personal achievement, such as lack of productivity and low confidence (Maslach \& Leiter, 2016). The symptoms of burnout are seen in employees who work at an intense pace and push themselves to exhibit exceptional performance (Özyer, Berk, \& Polatc1, 2016). It is a psychological prolonged syndrome that results in a response to stressors on the job (Maslach \& Leiter, 2016). (Rhoades \& Eisenberger, 2002) pointed out that as the employees are given the opportunities to be heard and being treated with respect in the administration of organizational policies, they are more likely to have a strong impression that the organization values their opinions, contributions and cares about their wellbeing. Their findings suggested that employees with higher POS are generally more pleasant about their jobs, in good mood at work, and experience fewer strain symptoms such as burnout, anxiety, and fatigue.

According to the job demand model (Demerouti, et al., 2001), social support is essential in reducing burnout syndrome. Thus, organizational support as a form of social support (Ahmed, et al., 2011) should be constantly provided to healthcare staff. Job burnout can lead to physical and psychological obstacles and minimize job efficiency, especially in complicated jobs such as healthcare jobs (Bazmi, et al., 2019). These jobs require sustainability of physical, emotional, and mental efforts; hence, it is associated with exhaustion and fatigue (Demerouti, et al., 2001). (Stinglhamber \& Vandenberghe, 2003) stated that providing employees with necessary organizational support can help them in effectively handling stressful situations. (Yaghoubi, Pourghaz, \& Toomaj, 2014) found a significant negative relationship between POS and job burnout, and the higher the level of POS the lower the level of burnout. (Özyer, Berk, \& Polatc1, 2016) investigated the effect of perceived organizational support on burnout in private healthcare staff and found a significant effect of POS on all dimensions of burnout (emotional, depersonalization, and inefficacy). In the same vein, (Neves, et al., 2014) study the POS as a predictor of job burnout, and their findings indicated the importance of work conditions and organizational support for healthcare professionals. They suggested that healthcare organizations should establish strategies to enhance work conditions and organizational support in order to prevent burnout syndromes and ensure a better quality of health services. In addition, (Grama \& Băiaș, 2018) found POS, emotional labor, and work frustration as predictors of burnout syndrome among medical staff. They suggested that as they spend most of their time at work, they need accurate working conditions, much support, and respect. This view is also 
supported by (Anomneze, Ugwu, Enwereuzor, \& Ugwu, 2016) findings that POS significantly predicts exhaustion at work. According to (Zeng, Zhang, Chen, Liu, \& Wu, 2020) POS has a significant negative predictive effect on workplace burnout.(Walters \& Raybould, 2007) found that the higher the level of POS the lower the levels of exhaustion and cynicism, and their findings suggested that social and environmental factors should be considered when studying burnout in the workplace. Based on the theory of POS, job demand model, and the above studies, the first hypothesis is proposed as follows:

H1: Perceived organizational support has a negative relationship with job burnout

\subsection{Perceived organizational support and organizational cynicism}

Organizational cynicism found to be associated with many undesirable outcomes such as decreased employees' commitment and increased turnover intention (Vveinhardt \& Pleskienè, 2018), organizational revenge, and stress (Özer et al., 2014). Cynicism is contagious (LOCKWOOD, 2018), and when cynicism started to spread throughout the organization, it damages the organizations' reputation and undermines its success (Dulnik, 2018). Organizational cynicism has three main dimensions, cognitive, affective, and behavioral cynicism (Dean, et al., 1998; Ince \& Turan, 2011; Erarslan, et al., 2018). Cognitive cynicism refers to a lack of loyalty, credibility, and trust in the company (Abraham, 2000), affective cynicism is an internal cynical feeling towards the company and is associated with symptoms such as tension and anxiety (Durrah, Chaudhary, \& Gharib, 2019), and behavioral cynicism is a reaction that results from cynical attitudes towards the company (James, 2005). POS is one of the underlying reasons of employees' cynicism towards their organizations (Guzel, Perçin, \& Tukelturk, 2011). (Kasalak \& Aksu, 2014) investigated the relationship between perceived organizational support and organizational cynicism and found the perceived level of organizational support predicts the level of cynicism employees experience towards their organizations. The study of (YAZICIOĞLU \& GENÇER, 2017) has revealed that when individuals experience unfair organizational practices their behaviors may become cynical. (Johnson \& O'Leary - Kelly, 2003) also claimed that cynicism is a reaction of employment-related social exchange violations. Cynicism arises when employees feel they are not treated appropriately (Maslach \& Leiter, 2016). In contrast, when the organization is perceived as fair and transparent, employees are less likely to exhibit cynical behaviors (Erdoğdu, 2018). (Dean, Brandes, \& Dharwadkar, 1998) argue that cynicism is not only a judgment and associated attuited towards the organization, but it can also include a strong and powerful emotional reaction. (SOYSAL, YAĞAR, \& ÖKE, 2017) examined the levels of perceived organizational support of health consultants and found that employer's support influences organizational cynicism. Poor perceived organizational support, especially from the managers contributes to cynicism development (Cole, Bruch, \& Vogel, 2006). According to (Çetin \& Karkin, 2018) the main source of organizational cynicism come from leadership support. A negative (Aly, Ghanem, \& El-Shanawany, 2016), and strong (Byrne, 2008) relationship was found between organizational cynicism and perceived organizational support. (PEPLINSKI, 2014; Özyer, \& Alici, 2019) pointed out the significant negative relationship between perceived organizational support and all dimensions of organizational cynicism. Based on the above, the study proposes the second hypothesis as follows:

H2: Perceived organizational support has a negative relationship with organizational cynicism.

\subsection{Job burnout and organizational cynicism}

Cynicism is an internal feeling towards the company (Nafe \& Kaif, 2013). Employees in high-demanding jobs use cynicism as a stressors-coping strategy (Abraham, 2000; Taries, et al., 2005). According to (Simha, et al. 2014), job burnout will turn into cynicism, and cynicism is a defensive mechanism that the person uses to prevent increasing levels of burnout. According to (WHO, 2019) cynicism and negativism are symptoms of burnout that result from inappropriately managed workplace stressors. (Eryesil \& Öztürk, 2016) advances knowledge by examining the relationship between organizational cynicism and burnout in the healthcare sector and the results showed a positive and statistically meaningful correlation between burnout and organizational cynicism. Studies of (Sunhyuk et al., 2019; Merrill, 2020) found that cynicism is decreased by employees' trust and transformational leadership and increased by job stress that consequently led to job burnout. (Akhigbe \& Oyam, 2017) investigated the relationship between burnout dimensions and organizational cynicism, and their findings indicated that emotional exhaustion and inefficacy are strong predictors of organizational cynicism. (Simha, Elloy, \& Huang, 2014) 's study has unfolded positive associations between components of job burnout (emotional exhaustion \& depersonalization) and organizational cynicism.

Overall, very few research studies have been carried out on the relationship between job burnout and organizational cynicism (Akhigbe \& Oyam, 2017), therefore, in response to call in literature to investigate the two variables, and to adequately study the relationship between burnout and cynicism (Simha, Elloy, \& Huang, 2014), the study proposes the third hypothesis as follows:

H3: job burnout has a positive relationship with cynicism. 


\subsection{The mediating effect of job burnout}

Job burnout is a problematic psychological state that occurs to employees due to stressors or demanding work conditions (Salvagioni, et al., 2017; Leiter \& Maslach, 2018). Organizational cynicism is a final reaction result from employees' negative attitudes towards the organization (AKÇAY, 2017; James, 2005). A large body of literature has confirmed a negative relationship between POS and job burnout (e.g., Zeng et al., 2020; Özyer et al., 2016; Alves et al., 2014; Grama \& Băiaș, 2018; Anomneze et al., 2016). Job burnout is also found to be positively associated with organizational cynicism (e.g., Akhigbe \& Oyam, 2017; Eryesil \& Öztürk, 2016; Sunhyuk, et al., 2019; Merrill, 2020).

According to the theory of social exchange proposed by (Blau, 1964), individuals' actions are motivated by what they expect to get in return, and this mechanism 'exchange' is reciprocal in nature. This theory forms the basis for perceived organizational support theory (Eisenberger et al., 1986; Ahmed et al., 2011). According to (Grama \& Băiaș, 2018) as medical staff spends most of their time at work, they need special working conditions, a high level of organizational support, and respect. When company policies, supervision, rewards, and work conditions are perceived poorly, employees tend to have higher levels of job burnout, as they feel neglected by their organizations (Zeng, Zhang, Chen, Liu, \& Wu, 2020). Drawing on SET and supporting (Abraham, 2000; Trais et al., 2005)'s notion that cynicism is a stressors-coping strategy, the current study proposes that POS affects organizational cynicism through the emotional state (i: e burnout); that is, job burnout plays a mediating role in the relationship between POS and organizational cynicism. In other words, POS indirectly affects organizational cynicism through burnout, which means that POS level might lead to or hinder the employees' cynicism through the experienced job burnout.

Based on that, the study proposes the fourth hypothesis as follows:

H4: Job burnout mediates the relationship between perceived organizational support and organizational cynicism.

\section{Methods and Measures}

A cross-sectional design method was adopted, and a quantitative method was employed as both were considered appropriate for the current study. The cross-sectional design has been used widely in many administrative and social sciences studies that have targeted large and diverse populations. This method allows taking a snapshot of a situation at a single point in time and analyzing it (Akhigbe \& Gail 2017). Employees in the Healthcare industry in Saudi Arabia represent the target population for this study. Data were collected using a structured online survey administrated via Monkey Survey and circulated within the authors' social and professional networks at a period of two weeks. The initial sample consisted of 223 medical and nonmedical employees, however, by adapting (Collier \& Bienstock, 2007) recommendation all forms with missing data were eliminated, and only 211 questionnaires were usable. The medical staff represents $75.8 \%$ of the total sample and nonmedical personnel represents $24.2 \%$ of the total respondents.

To measure organizational cynicism, Organizational Cynicism Scale (OCS) with 13-items proposed by (Dean, et al., 1998) was used. It aims at measuring three main dimensions of cynicism: cognitive, emotional, and behavioral. It has been used by many scholars to measure cynicism of healthcare personnel, for instance (Sungur, et al., 2019) who conducted a study in the same field. Participants responded to statements such as "I find myself mocking up my organization's slogans and initiatives" using the 1-5 Likert Scale; where 1= completely disagree, $5=$ completely agree. Maslach Burnout Inventory (MBI) with 22-items which was developed by (Maslach \& Jackson, 1981) was used to measure the degree to which staff experience emotional exhaustion, depersonalization, and inefficacy in the workplace. It is widely used by researchers to measure burnout syndromes of healthcare staff in the workplace such as (de, et al., 2017; Pappa, et al., 2021; Leonardi, Pagani, Giovannetti, Raggi, \& Sattin, 2013). Participants responded to statement such as "I feel like I'm at the end of my rope" and "Working with people all day really is a strain for me" using the 1-5 Likert Scale; where 1=never, 5= always. The unidimensional 8-items scale recommended by (Rhoades \& Eisenberger, 2002) was used to measure the Perceived Organizational Support of healthcare staff in Saudi Arabia. This scale is widely available and was already used in healthcare field studies such as (Al-Omar, et al., 2019). Participants responded to statements such as "The organization really cares about my well-being" using the 1-5 Likert Scale; where 1= completely disagree, $5=$ completely agree. The survey also used 4 demographic questions concerning age, job type, employment type, and years of experience with the current organization. Table1 shows the demographic characteristics of the study respondents, and Table2 shows the corresponding Cronbach's $\alpha$ of each measure for the study. 
Table1. Demographic Characteristics of Study Participants $(n=211)$

\begin{tabular}{|c|c|c|}
\hline Variables & Percent (\%) & $\begin{array}{c}\text { Mean } \\
\text { (S.D) } \\
\end{array}$ \\
\hline $\begin{array}{l}\text { Job Type: } \\
\text { Medical } \\
\text { Non-Medical }\end{array}$ & $\begin{array}{l}75.8 \% \\
24.2 \% \\
\end{array}$ & $\begin{array}{c}1.24 \\
(.429)\end{array}$ \\
\hline $\begin{array}{l}\text { Employment Type: } \\
\text { Part-Time } \\
\text { Full-Time } \\
\text { Other }\end{array}$ & $\begin{array}{c}13.7 \% \\
79 \% \\
6.6 \% \\
\end{array}$ & $\begin{array}{c}1.93 \\
(.447)\end{array}$ \\
\hline $\begin{array}{l}\text { Age: } \\
\text { Less than } 20 \\
20 \text { to less than } 30 \\
30 \text { to less than } 40 \\
40 \text { to less than } 50 \\
50 \text { and above }\end{array}$ & $\begin{array}{c}1.9 \% \\
45.5 \% \\
30.3 \% \\
16.1 \% \\
6.2 \%\end{array}$ & $\begin{array}{c}2.79 \\
(.948)\end{array}$ \\
\hline $\begin{array}{l}\text { Years of experience with current } \\
\text { employer: } \\
\text { Less than } 3 \text { years } \\
3 \text { to less than } 5 \text { years } \\
5 \text { to less than } 10 \text { years } \\
10 \text { to less than } 15 \text { years } \\
15 \text { and above }\end{array}$ & $\begin{array}{c}37 \% \\
16.6 \% \\
20.4 \% \\
10.9 \% \\
15.2 \%\end{array}$ & $\begin{array}{c}2.51 \\
(1.459)\end{array}$ \\
\hline
\end{tabular}

\section{Results}

\subsection{Validity and Reliability}

To check model validity and reliability three methods were applied using smart PLS 3: (the internal reliability through "factor loadings $\geq 0.50$, Average Variance Extracted "AVE $\geq .5$ ", Cronbach's alpha " $\alpha \geq .5$ ", Composite reliability $\geq 0.7$ (Hair et al., 2010).

Table 2. Result of Construct Assessment

\begin{tabular}{|c|c|c|c|c|}
\hline Items & $\begin{array}{l}\text { Factor } \\
\text { Loading }\end{array}$ & $\begin{array}{l}\text { Cronbach's } \\
\boldsymbol{\alpha}\end{array}$ & $\mathbf{C R}$ & AVE \\
\hline \multicolumn{5}{|l|}{ Perceived Organizational Support } \\
\hline "The organization strongly considers my goals and values". & 0.672 & \multirow{8}{*}{0.863} & \multirow{8}{*}{0.879} & \multirow{8}{*}{0.531} \\
\hline "Help is available from the organization when I have a problem". & 0.772 & & & \\
\hline "The organization really cares about my well-being". & 0.758 & & & \\
\hline "The organization would forgive an honest mistake on my part". & 0.692 & & & \\
\hline $\begin{array}{l}\text { "The organization is willing to help me when I need a special } \\
\text { favour". }\end{array}$ & 0.802 & & & \\
\hline $\begin{array}{l}\text { "If given the opportunity, the organization would take advantage of } \\
\text { me". }\end{array}$ & 0.609 & & & \\
\hline "The organization shows very little concern for me". & 0.748 & & & \\
\hline "The organization cares about my opinions". & 0.760 & & & \\
\hline \multicolumn{5}{|l|}{ Job burnout } \\
\hline "I feel emotionally drained from my work". & 0.717 & \multirow{11}{*}{0.806} & \multirow{11}{*}{0.865} & \multirow{11}{*}{0.554} \\
\hline "I feel used up at the end of the workday". & 0.663 & & & \\
\hline $\begin{array}{l}\text { "I feel fatigued when I get up in the morning and have to face } \\
\text { another day on the job". }\end{array}$ & 0.723 & & & \\
\hline "Working with people all day really is a strain for me". & 0.621 & & & \\
\hline "I feel burned out from my work". & 0.547 & & & \\
\hline "I worry that this job is hardening me emotionally". & 0.646 & & & \\
\hline "I feel frustrated by my job". & 0.659 & & & \\
\hline "I feel I'm working too hard on my job". & 0.539 & & & \\
\hline "I don't really care what happens to some co-workers or patients". & 0.704 & & & \\
\hline "Working with people directly puts too much stress on me". & 0.778 & & & \\
\hline "I feel happy and energetic". & 0.667 & & & \\
\hline
\end{tabular}




\begin{tabular}{|c|c|c|c|c|}
\hline Items & $\begin{array}{l}\text { Factor } \\
\text { Loading }\end{array}$ & $\begin{array}{c}\text { Cronbach's } \\
\boldsymbol{\alpha}\end{array}$ & $\mathbf{C R}$ & AVE \\
\hline $\begin{array}{l}\text { "I feel exhilarated after working closely with my co-workers or } \\
\text { patients". }\end{array}$ & 0.712 & & & \\
\hline "I feel like I'm at the end of my rope". & 0.647 & & & \\
\hline "I feel co-workers or patients blame me for some of their problems". & 0.766 & & & \\
\hline \multicolumn{5}{|l|}{ Organizational Cynicism } \\
\hline "I believe my organization says one thing and does another". & 0.722 & & & \\
\hline $\begin{array}{l}\text { "My organization's policies, goals, and practices seem to be in } \\
\text { alignment". }\end{array}$ & 0.681 & & & \\
\hline $\begin{array}{l}\text { "When my organization says it's going to } \\
\text { do something, I wonder if it will really happen". }\end{array}$ & 0.566 & 0.870 & 0.909 & 0.510 \\
\hline $\begin{array}{l}\text { "My organization expects one thing of its employees, but rewards } \\
\text { another". }\end{array}$ & 0.736 & & & \\
\hline "When I think about my organization, I experience aggravation". & 0.720 & & & \\
\hline $\begin{array}{l}\text { "I see little similarity between what my organization says it will do } \\
\text { and what it actually does". }\end{array}$ & 0.629 & & & \\
\hline "When I think about my organization, I get angry". & 0.609 & & & \\
\hline "When I think about my organization, I get tense". & 0.640 & & & \\
\hline "When I think about my organization, I feel a sense of anxiety". & 0.821 & & & \\
\hline $\begin{array}{l}\text { "I complain about what is happening in the work to my friends } \\
\text { beyond my organization". }\end{array}$ & 0.649 & & & \\
\hline $\begin{array}{l}\text { "I often talk to others about the ways things are run in my } \\
\text { organization". }\end{array}$ & 0.831 & & & \\
\hline "I criticize my organization practices and policies with others". & 0.807 & & & \\
\hline "I find myself mocking my organization's slogans and initiatives". & 0.804 & & & \\
\hline
\end{tabular}

As shown in Table 2 all factor loadings exceeded .50, except 8 items in the Maslach burnout scale, and were eliminated as they were under the minimum value. Cronbach's alpha ranges from .806 to .870 , the average variance extracted (AVE) by each variable was above 0.50 , suggesting evidence of convergent validity among our measures (Hair et al., 2019). Moreover, the value of composite reliability (CR) is more than 0.7 . The above table shows that $\mathrm{CR}$ values ranged from 0.879 to 0.909 . The current outcomes provide evidence of convergent and discriminant validity for the study proposed model constructs, which means that the authors can proceed with further analysis.

\subsection{Testing Research Model \& Hypothesis}

(Hair, et al., 2019) recommended that smart PLS can be applied if the sample above 200. Referring to the study sample size and data collection, IBM SPSS version 25 and Smart PLS 3 were applied to conduct structural equation modeling (SEM) for diagnosing not only the measurement model but also the structure of the variables. SEM helps and supports researchers to investigate interrelationships between research variables, and it provides useful statistical procedures to investigate complex models (Hair et al., 2006).

Against this backdrop, the present study makes an attempt to ascertain and further our understanding concerning the interaction among the aforementioned variables. The outcome presented in Table 3 and Figure 2 provided support for the research hypotheses. Detailed information and directions of the hypotheses will be discussed in the following paragraphs. 


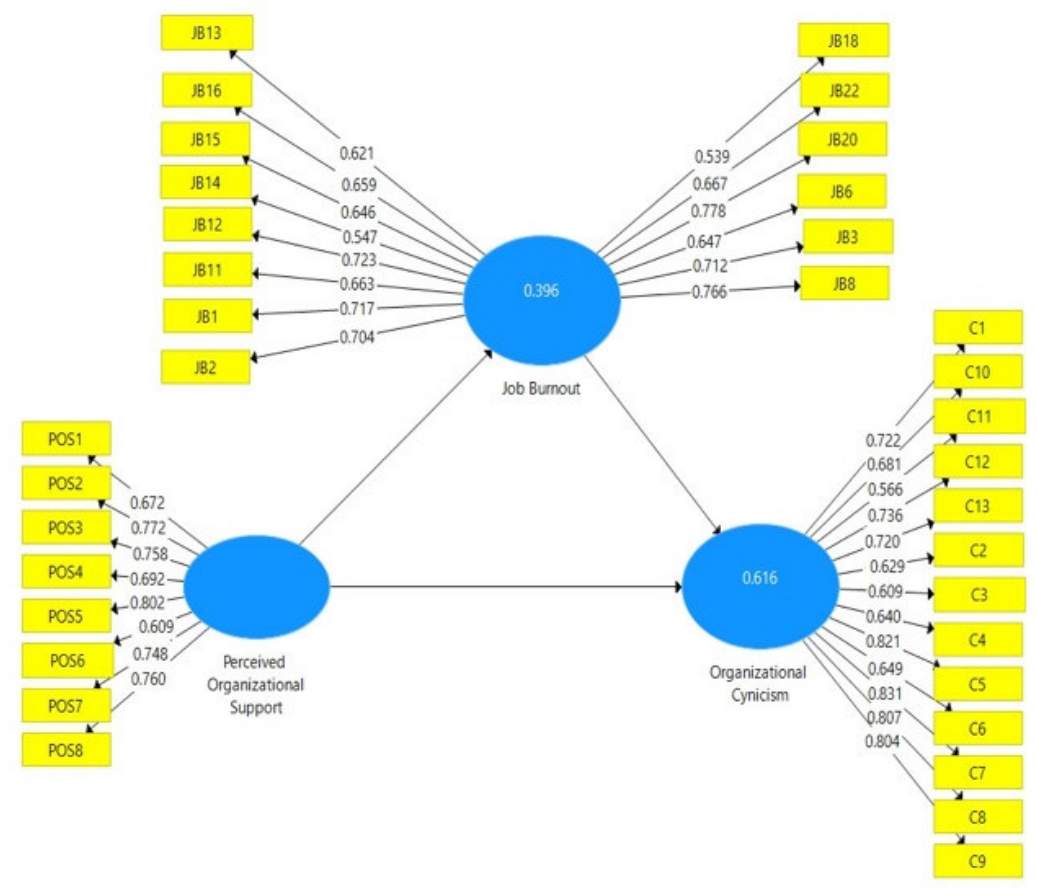

Figure 2. Path Model

Table 3. Summary of Hypothesis Testing Results

\begin{tabular}{llccccc}
\hline \multicolumn{1}{c}{ Path (hypothesis) } & $\boldsymbol{\beta}$ & $\begin{array}{c}\text { Standard } \\
\text { Deviation }\end{array}$ & $\begin{array}{c}\text { T } \\
\text { Statistics }\end{array}$ & P Values & Result \\
\hline $\mathbf{1}$ & $\begin{array}{l}\text { Perceived Organizational Support-> } \\
\text { Job Burnout }\end{array}$ & -0.629 & 0.043 & 14.550 & 0.000 & Supported \\
\hline $\mathbf{2}$ & $\begin{array}{l}\text { Perceived Organizational Support-> } \\
\text { Organizational Cynicism }\end{array}$ & -0.511 & 0.053 & 9.675 & 0.000 & Supported \\
\hline $\mathbf{3}$ & $\begin{array}{l}\text { Job Burnout -> Organizational } \\
\text { Cynicism }\end{array}$ & 0.355 & 0.056 & 6.373 & 0.000 & Supported \\
\hline $\mathbf{4}$ & $\begin{array}{l}\text { Perceived Organizational Support->- } \\
\text { Job Burnout >- Organizational } \\
\text { Cynicism }\end{array}$ & 0.223 & 0.042 & 5.306 & 0.000 & Supported \\
\hline
\end{tabular}

Hypothesis 1 predicted that perceived organizational support has a negative relationship with job burnout $(\mathrm{t}$ $=14.550 \rho<.05$ ). The outcome conforms to this prediction as perceived organizational support explains $39.6 \%$ percent of job burnout variance. Thus hypothesis 1 was supported. Hypothesis 2 predicted that perceived organizational support negatively related to organizational cynicism $(t=9.675, \rho<.05)$. The outcome conforms to this prediction, thus, hypothesis two was supported. Hypothesis 3 predicted that job burnout positively related to organizational cynicism $(\mathrm{t}=6.373, \rho<.05)$. The outcome conforms to this prediction as job burnout and perceived organizational support explain $61.6 \%$ percent of organizational cynicism. Thus, hypothesis 3 was supported. Finally, Hypothesis 4 predicted that job burnout mediates the relationship between perceived organizational support and organizational cynicism $(t=5.306, \rho<.05)$. The outcome conforms to this prediction. Further confidence intervals bias-corrected estimates results suggested that $(\rho=.000,95 \%$ confidence interval: $(0.139$ and 0.308$)$ as zero is not in the confidence interval, therefore, job burnout is considered to have a mediating effect based on (Preacher \& Hays 2007) rule of mediation.

Table 4. Goodness of Fit of the Model

\begin{tabular}{l|l}
\hline \multicolumn{1}{c|}{ Goodness-of-fit indices } & \multicolumn{1}{c}{ Cut-off points } \\
\hline $\mathrm{DF}=525, \mathrm{p}<.001$ & $1=$ maximum fit \\
\hline $\mathrm{CFI}=.913$ & $1=$ maximum fit \\
\hline $\mathrm{TLI}=.902$ & Values $<.08$ indicating good fit \\
\hline $\mathrm{RMSEA}=.057$ &
\end{tabular}

To further test the study model, many goodness-of-fit indices were applied using IBM AMOS 26 referring to (Anderson \& Gerbing, 1988) recommendations. These indices include the Comparative Fit Index $(\mathrm{CFI})=.913$, Root Mean Square Error of Approximation $($ RMSEA $)=.057$, the Tucker-Lewis Index $(T L I)=.902$, with Degree 
of Freedom $(\mathrm{df})=525$ and $\mathrm{p}<.001$. The results show that the model fit indices are reasonable and acceptable as per suggestions from (Tanaka \& Huba, 1985); and (Wheaton, et al., 1977) where CFI cut-off point is 1 which represent maximum fit, RMSEA cut-off point should be less than .08 , TLI $=1$ represent a maximum fit. The above table illustrates the result of fit indices.

\section{Discussion}

The main objectives of the current study were to determine whether POS significantly reduces job burnout and organizational cynicism and whether job burnout plays a mediating role in the relationship between POS and organizational cynicism. All proposed relationships were supported. The results indicated that the level of perceived organizational support is an antecedent of burnout syndrome experienced at work by employees in the medical sector, and the analysis showed that POS has a significant negative effect on personnel job burnout. The findings are consistent with previous studies such as (Zeng et al., 2020; Özyer et al., 2016; Yaghoubi et al., 2014; Alves et al., 2014; Grama \& Băiaș, 2018; Walter \& Raybould, 2007; Anomneze et al., 2016). In the same vein, we argue that employees who perceive their organizations as supportive and caring are less likely to experience a high level of burnout in their jobs. When the employees feel that their opinions are being heard, their contributions are valued and their well-being is considered, they view their organizations positively (Rhoades \& Eisenberger, 2002), and consequently results in reduced job burnout. Employees with a high level of POS are more likely to be pleasant and in good mood at work and less likely to experience strain symptoms such as burnout (Rhoades \& Eisenberger, 2002).

The results also supported the second proposed hypothesis. It was found that the level of perceived organizational support is a significant predictor of organizational cynicism among healthcare staff. The study results confirmed the findings of (Kasalak \& Aksu, 2014; Guzel et al., 2011; SOYSAL et al., 2017; Aly et al., 2016; Byrne, 2008; PEPLINSKI, 2014). Similarly, we argue that when the organization is perceived as supportive and its policies and practices are in alignment, its employees are less likely to exhibit cynicism at work. A low level of POS results in employees' cynical attitudes, emotions, and behaviors. When the employees are cynical, they are more likely to experience negative emotions when they even think about their organizations, these emotions might include tension, anger, anxiety, and aggravation (Dean, et al., 1998).

The results supported the third proposed hypothesis that job burnout positively associated with organizational cynicism. Therefore, we argue that burnout experienced at work would consequently result in organizational cynicism. The current study results confirmed the findings of (Akhigbe \& Oyam, 2017; Simha, et al., 2014; Eryesil \& Öztürk, 2016; Sunhyuk, et al., 2019; Merrill, 2020) which found a significant and meaningful relationship between job burnout and organizational cynicism. Finally, the fourth proposed hypothesis was supported, and an indirect relationship between perceived organizational support and organizational cynicism was found. Based on (Preacher \& Hays, 2007) rule of mediation, job burnout is mediating the relationship between POS and organizational cynicism. Thus, we argue that perceived organizational support influences the level of organizational cynicism through mediating role of job burnout. As burnout is properly managed through perceived organizational support, it is less likely to contribute to cynicism formation. In contrast, lack of necessary organizational support to allay job burnout would result in an intense level of cynicism.

The current paper is the first study that investigates POS, job burnout, and organizational cynicism of healthcare staff in a single study. It offers some important insights into the growing body of literature in negative observed phenomena such as burnout and cynicism, and in soliciting the appropriate organizational intervention to ameliorate them.

\subsection{Practical implications}

The current study has many practical implications for healthcare organizations and HR professionals seeking to enhance their work atmospheres. First, healthcare organizations should consider the support it provides to their employees as an investment and should design appropriate interventions to minimize the negative impact of cynicism and job burnout. Second, based on the findings of the study, we suggest that healthcare organizations should align their policies and practices with their goals in order to reduce cynicism among their staff. Healthcare organizations should understand that organizational cynicism is a phenomenon that negatively influences employees' behaviors and might result in arbitrary grievances, criticism, and mocking up any organizational initiatives. Third, given the positive influence of POS on employees, organizations should pay attention to the signals they send to their employees, as a negative signal might contribute to the formation of cynicism and worsen the experienced burnout syndrome at work. Finally, given that POS is more likely to alleviate burnout, organizations should create different types of organizational support, specifically, the types of support should fit with the types of stressors (Cohen \& Wills, 1985). 


\subsection{Limitations}

Although the study results in many findings and practical implications, it has certain limitations. First, the study sample was limited to the healthcare staff in Saudi Arabia, which might obscure the generalizability of the result. Further studies analyzing the proposed model in different sectors and other cultural contexts may result in deeper insights. Second, the study used only perceived organizational support as a predictor of levels of job burnout and organizational cynicism. Future empirical studies can investigate other environmental factors and their influences on burnout and cynicism. Finally, data were collected from a single source and a cross-sectional design was used in the study, however, the scope of the study can be improved by longitudinal survey design.

\section{Conclusion}

The current paper proposes a theoretical model and represents an attempt to explore whether perceived organizational support reduces job burnout and organizational cynicism and whether job burnout plays a mediating role in the relationship between POS and organizational cynicism. When tested, all proposed hypotheses were supported. The study unfolds that perceived organizational support alleviates burnout syndrome and cynicism experienced at work, and job burnout is mediating the relationship between perceived organizational support and organizational cynicism. The paper has argued that perceived organizational support affects the level of organizational cynicism through job burnout. When burnout is properly managed through organizational support, it is less likely to contribute to cynicism formation, and when poorly managed through organizational support it would result in an intense level of cynicism. Finally, the study suggested that perceived organizational support should be given more attention by healthcare organizations, as it creates positive employees responses, improves their psychological and emotional well-being, and enhances their behaviors towards the organizations.

\section{References}

Abraham, R. (2000). Organizational Cynicism: Bases and Consequences. Genetic, Social \& General Psychology Monographs, 269-292.

Ahmed, I., Ismail, W. K., Amin, S. M., \& Ramzan, M. (2011). Conceptualizing Perceived Organizational Support: A Theoretical Perspective. Australian Journal of Basic and Applied Sciences, 784-789.

AKÇAY, V. H. (2017, December). Cynicism at Universities: A Research Based on Pervasion of Academics' Cynicism and its Relationship with Performance. In V. H. AKÇAY, Current Trends in Educational Sciences (pp. 537-551). Ankara: Sofia.

Akhigbe, O. J., \& Oyam, J. G. (2017, August). Job Burnout and Organizational Cynicism Among. European Scientific Journal, p. 125.

Al-Omar, H. A., Arafah, A. M., Barakat, J. M., Almutairi, R. D., Khurshid, F., \& Alsultan, M. S. (2019). The Impact of Perceived Organizational Support and Resilience on Pharmacists' Engagement in Their Stressful and Competitive Workplaces in Saudi Arabia. Saudi Pharmaceutical Journal, 1044-1052.

Al-Omari, A., Al Mutair, A., Shamsan, A., \& Al Mutairi, A. (2019, December). Predicting Burnout Factors among Healthcare. Applied Sciences, pp. 2-8.

Aly, N. A.-F., Ghanem, M., \& El-Shanawany, S. (2016). Organizational Cynicism and Its Consequences on Nurses and. Journal of Education and Practice, pp. 87-94.

Anderson, J. C., \& Gerbing, D. W. (1988). Structural equation modeling in practice: A review and recommended two-step approach. Psychological bulletin, 103(3), 411.

Anomneze, E., Ugwu, D., Enwereuzor, I., \& Ugwu, L. (2016). Teachers' Emotional Labour and Burnout: Does Perceived Organizational Support Matter? Asian Social Science, 9-22.

Bazmi, E., Alipour, A., Yasamy, M., Kheradmand, A., Salehpour, S., Khodakarim, S., \& Soori, H. (2019, December). Job Burnout and Related Factors among Health Sector Employees. Iranian Journal of Psychiatry, pp. 309-310.

Blau, P. (1964). Exchange and Power in Social Life. New York: Wiley, 88-97.

Byrne, Z. S. (2008). Perceived Organizational Support \& Performance Relationships Across Levels of Organizational Cynicism. Journal of Managerial Psychology, pp. 60-68.

Çetin, A., \& Karkin, N. (2018, February). Cynicism as Mediating Variable Between Leadership Support and Emotional Burnout: Administrative Support Staff in Turkish Universities. Transylvanian Review, pp. 5-6.

Cohen, S., \& Wills, T. (1985). Stress, Social Support, and the Buffering Hypothesis. Psychological Bulletin, 310 357.

Cole, M. S., Bruch, H., \& Vogel, B. (2006). Emotion as Mediators of the Relations Between Perceived Supervisor Support and Psychological Hardiness On Employee Cynicism. Journal of Organizational Behaviour, 463-484.

Collier, J. E., \& Bienstock, C.C. (2007). An Analysis of How Non-Response Error Is Assessed in Academic Marketing Research. Marketing theory, 7(2), 163-183. 
De, P. L., rio, A. C., China, E. L., \& Goncalves, A. K. (2017). Burnout Syndrome In Health-Care Professionals in a University Hospital. Clinics, 305-309.

Dean, J., Brandes, P., \& Dharwadkar, R. (1998). Organizational Cynicism. Academy of Management Review, 341-352.

Demerouti, E., Schaufeli, W. B., \& Nachreiner, F. (2001). The Job Demands-Resources Model of Burnout. Journal of Applied Psychology, 499-512.

Dulnik, A. (2018, November 20). Coaching Leaders Through Organizational Cynicism. Retrieved from Forbes: https:/www.forbes.com/sites/forbescoachescouncil/2018/11/20/coaching-leaders-through-organizational cynicism/?sh=3cc0924714df

Durrah, O., Chaudhary, M., \& Gharib, M. (2019). Organizational Cynicism and Its Impact on. International Journal of Environmental Research and Public Health, pp. 2-14.

Eisenberger, R., Huntington, R., Hutchison, S., \& Sowa, D. (1986). Perceived Organizational Support. Journal of Applied Psychology, 500-507.

Erdoğdu, M. (2018). Effect of Organizational Justice Behaviors on Organizational Silence and Cynicism: A Research on Academics from Schools of Physical Education and Sports. Universal Journal of Educational Research, pp. 737-738.

Eryesil, K., \& Öztürk, M. (2016). The Relationship Between Organizational Cynicism and Burnout: A Field Research in Health Sector. Second Sarajevo International Conference on Social Sciences (p. 48). Sarajevo: Second Sarajevo International Conference.

George, J. M., Reed, T. F., Ballard, K. A., Colin, J., \& Fielding, J. (1993). Contact with AIDS patients as a source of work-related distress: Effects of organizational and social support. Academy of Management Journal, 157-171.

Grama, B. G., \& Băiaș, M. (2018). Organizational Support, Emotional Labor And Burnout Regarding The Medical Staff. Public Health And Management, 16-19.

Guzel, B., Perçin, N. S., \& Tukelturk, S. A. (2011). The Relationship of Perceived Organizational Support With Organizational Cynism and Its Effects on Turnover Intent: A Research On 4 And 5 Star Hotels. Revista Tinerilor Economisti (The Young Economists Journal), 198-215.

Hair, J. F., Anderson, R. E., Babin, B. J., \& Black, W. C. (2010). Multivariate data analysis: A global perspective (Vol. 7): Pearson Upper Saddle River.

Hair, J. F., Black, W. C., Babin, B. J., Anderson, R. E., \& Tatham, R. L. (2006). Multivariate data analysis (Vol. 6).

Hair, J. F., Risher, J. J., Sarstedt, M., \& Ringle, C. M. (2019). When to use and how to report the results of PLSSEM. European Business Review.

James, M. S. (2005, Semester). Antecedents and Consequences of Cynicism. Florida State University Libraries, pp. 13-30.

Johnson, J. L., \& O'Leary - Kelly, A. M. (2003). The effects of psychological contract breach and organizational cynicism: Not all social exchange violations are created equal. Journal of Organizational Behavior, 627-647.

Kasalak, G., \& Aksu, M. B. (2014). The Relationship between Perceived Organizational Support and Organizational Cynicism of Research Assistants. Educational Sciences: Theory \& Practice, 125-133.

Ksiazek, I., Stefaniak, T. J., Stadnyk, M., \& ziazek, J. K. (2011). Burnout syndrome in surgical oncology and general surgery nurses: A cross-sectional study. European Journal of Oncology Nursing, 347-350.

Leiter, M. P., \& Maslach, C. (2018, September 11). Interventions to Prevent and Alleviate Burnout. Retrieved from Current Issues in Work and Organizational Psychology Routledge: https://www.routledgehandbooks.com/doi/10.4324/9780429468339-3

Leonardi, M., Pagani, M., Giovannetti, A. M., Raggi, A., \& Sattin, D. (2013). Burnout in healthcare professionals working with patients with disorders of consciousness. Work, 45(3), 349-356.

LOCKWOOD, C. J. (2018, Apr). Burnout and depression in medical students and mentors: Cynicism is contagious, but we can take steps to bring joy back to our specialty. Contemporary OB/GYN (CONTEMP OB GYN), pp. 5-7.

Maslach, C., \& Jackson, S. E. (1981). The measurement of experienced burnout. Journal of Occupational Behaviour, 99-113.

Maslach, C., \& Leiter, M. P. (2008). Early Predictors of Job Burnout and Engagement. Journal of Applied Psychology, 498-512.

Maslach, C., \& Leiter, M. P. (2016). Understanding the Burnout Experience: Recent Research \& Its Implications For Psychiatry. Official Journal of the World Psychiatric Association (WPA), 1-9.

Maslach, C., Jackson, S., \& Leiter, M. (1997). Maslach Burnout Inventory. Lanham: In C. P. Zalaquett \& R. J. Wood (Eds.), Evaluating stress.

Maslach, C., Schaufeli, W. B., \& Leiter, M. P. (2001). Job Burnout . Annual Review of Psychology , 397-422.

Merrill, D. A. (2020, April 27). What is burnout? How to recognize the signs and recover from work-related 
stress. Retrieved from The American Institute of Stress: https://www.stress.org/what-is-burnout-how-torecognize-the-signs-and-recover-from-work-related-stress

Nafe, W. A., \& Kaif, d. (2013). The Impact of Organizational Cynicism on Organizational Commitment: An Applied Study on Teaching Hospitals in Egypt. European Journal of Business and Management, p. 131.

Neves, V. F., Oliveira, Á. d., \& Alves, P. C. (2014). Síndrome de Burnout: Impacto da Satisfação no Trabalho e da Percepção de Suporte Organizacional. Psico, 45-54.

NURKA, NURKA, LJILJANA, M., \& BILIC. (2014, OCTOBER). Doctors, Depersonalization or Cynicism as Dimension of Burnout Among Medical. Peer Reviewed International Journal of Asian, p. 284.

Özer, O., Sonğur, C., Kar, A., Top, M., \& Erigüç, G. (2014). Organizational Stress, Organizational Cynicism, Organizational Revenge, Intention to Quit: A Study on Research Assistants. The Macrotheme Review, 121128.

Özyer, K., \& Alici, i. (2019). The Relationship Between Perceived Organizational Support With Organizational Cynicism and Sub-Dimension: An Empirical Study. 2nd International Conference on Contemporary Issues in Business \& Economics (ICCIBE). Tokat, Turkey.

Özyer, K., Berk, A., \& Polatc1, S. (2016). Does the Perceived Organizational Support Reduce Burnout? A Survey on Turkish Health Sector. International Journal of Business Administration and Management Research Vol 2(1) Jan-Mar 2016, 22-27.

Pappa, S., Athanasiou, N., Sakkas, N., Patrinos, S., Sakka, E., Barmparessou, Z., . . Katsaounou, P. (2021). From Recession to Depression? Prevalence and Correlates of Depression, Anxiety, Traumatic Stress and Burnout in Healthcare Workers during the COVID-19 Pandemic in Greece: A Multi-Center, Cross-Sectional Study. Int. J. Environ. Res. Public Health, 1-16.

PEPLINSKI, M. (2014). Perceived Organizational Support, Organizational Cynicism and Employee. The University of Waikato, pp. 37-38.

Perrewé, P. L., \& Zellars, K. L. (1999). An Examination of Attributions and Emotions in the Transactional Approach to the Organizational Stress Process. Journal of Organizational Behavior, 739-752.

Preacher, K. J., Rucker, D. D., \& Hayes, A. F. (2007). Addressing Moderated Mediation Hypotheses: Theory, Methods, and Prescriptions. Multivariate Behavioral Research, 42(1), 185-227.

Rhoades, L., \& Eisenberger, R. (2002). Perceived Organizational Support: A Review of the Literature. Journal of Applied Psychology, 698-714.

Rhoades, L., \& Eisenberger, R. (2002). Perceived Organizational Support: A Review of the Literature. Journal of Applied Psychology, 698-714.

Salvagioni DAJ, Melanda FN, Mesas AE, Gonza'lez AD, Gabani FL, Andrade SMd (2017). Physical, psychological and occupational consequences of job burnout: A systematic review of prospective studies. Plos One.

Seher Erarslan, Kaya, Ç., \& Altindag, E. (2018). Effect of organizational cynicism and job satisfaction on organizational. The Journal of Faculty of Economics and Administrative Sciences, pp. 905-922.

Seher Erarslan, Kaya, C.., \& Altindag, E. (2018). Effect Of Organizational Cynicism And Job Satisfaction on Organizational Commitment: An Empirical Study On Banking Sector. The Journal of Faculty of Economics and Administrative Sciences, pp. 905-922.

Simha, A., Elloy, D. F., \& Huang, H. C. (2014). The Moderated Relationship Between Job Burnout and Organizational Cynicism. Management Decision, 482-504.

SOYSAL, A., YAĞAR, F., \& ÖKE, P. (2017). An Analysis of The Levels of Health Consultants' Organizational Support and Organizational Cynicism. Business \& Management Studies: An International Journal, pp. 174175.

Stinglhamber, F., \& vandenberghe, C. (2003). Organizations and supervisors as sources of support and targets of commitment: a longitudinal study. Journal of Organizational Behavior, 251-270.

Sungur, C., Özer, Ö., Saygili, M., \& Uğurluoğlu, Ö. (2019). Paternalistic Leadership, Organizational Cynicism, and Intention to Quit One's Job in Nursing. Hospital Topics, 139-147.

Sunhyuk, K., Jung, K., Noh, G., \& Kang, L. K. (2019). What makes employees cynical in public organizations? Antecedents. Social Behavior and Personality, pp. 1-2.

Tanaka, J. S., \& Huba, G. J. (1985). A fit index for covariance structure models under arbitrary GLS estimation. British journal of mathematical and statistical psychology, 38(2), 197-201.

Taris, T. W., LeBlanc, P. M., Schaufeli, W. B., \& Schreurs, P. J. G. (2005). Are there causal relationships between the dimensions of the Maslach Burnout Inventory? A review and two longitudinal tests. Work \& Stress, 19, $238-255$.

http://dx.doi.org/10.1080/02678370500270453

Vveinhardt, J., \& Pleskienè, A. M. (2018). The quintessence of organizational commitment and Organizational cynicism. Management of Organizations: Systematic Research, 67-88.

Walters, G., \& Raybould, M. (2007). Burnout and Perceived Organisational Support Among Front-Line 
Hospitality Employees. Journal of Hospitality and Tourism Management, 14(2), 144-156.

Wheaton, B., Muthen, B., Alwin, D. F., \& Summers, G. F. (1977). Assessing Reliability and Stability in Panel Models. Sociological methodology, 8, 84-136.

WHO. (2019, May 28). Burn-out an "occupational phenomenon": International Classification of Diseases. Retrieved from World Health Organization: https://www.who.int/news/item/28-05-2019-burn-out-anoccupational-phenomenon-international-classification-of-diseases

Yaghoubi, N. M., Pourghaz, A., \& Toomaj, H. G. (2014). Study of Perceived Organizational Support's Relationship with Job Burnout. International Journal of Academic Research in Business and Social Sciences, 315-324.

YAZICIOĞLU, İ., \& GENÇER, E. Ö. (2017). The Effect of Organizational Justice Perception on Cynicism: A Research in Vocational School of State Universities. Journal of Business Research Turkey, 106-119.

Zeng, X., Zhang, X., Chen, M., Liu, J., \& Wu, C. (2020). The Influence of Perceived Organizational Support on Police Job Burnout: A Moderated Mediation Model. Frontiers in Psychology, 1-11. 